\title{
Beneficial Effects of Biochar and Chitosan on Antioxidative Capacity, Osmolytes Accumulation, and Anatomical Characters of Water-Stressed Barley Plants
}

\author{
Yaser Hafez ${ }^{1}{ }^{1}$, Kotb Attia ${ }^{2,3}$, Salman Alamery ${ }^{2}$, Abdelhalim Ghazy ${ }^{4}$, Abdullah Al-Doss ${ }^{4}$, \\ Eid Ibrahim ${ }^{4}$ (D), Emad Rashwan ${ }^{5}$, Lamiaa El-Maghraby ${ }^{6}$, Ahmed Awad ${ }^{6}$ and \\ Khaled Abdelaal ${ }^{1, *(D)}$ \\ 1 EPCRS Excellence Center, Plant Pathology and Biotechnology Laboratory, Agricultural Botany Department, \\ Faculty of Agriculture, Kafrelsheikh University, Kafr Elsheikh 33516, Egypt; hafezyasser@gmail.com \\ 2 Center of Excellence in Biotechnology Research, King Saud University, Riyadh POX 2455-11451, \\ Saudi Arabia; kattia1.c@ksu.edu.eg (K.A.); ksmatti@yahoo.com (S.A.) \\ 3 Rice Biotechnology Lab, Rice Research \& Training Center, Field Crops Research Institute, Sakha, \\ Kafr EL-Sheikh 33516, Egypt \\ 4 Plant Production Department, Food Science and Agricultural College, King Saud University, \\ Riyadh POX 2455-11451, Saudi Arabia; Abdelhalimghazi3@gmail.com (A.G.); \\ abdallahaldos3@gmail.com (A.A.-D.); eed4a@yahoo.com (E.I.) \\ 5 Agronomy Department, Faculty of Agriculture, Tanta University, Tanta 31111, Egypt; \\ plant_breeding2000@yahoo.com \\ 6 Agricultural Biochemistry Department, Faculty of Agriculture, Zagazig University, Zagazig 44511 Egypt; \\ dr_lamiaa222@yahoo.com (L.E.-M.); ahmedawad222@yahoo.com (A.A.) \\ * Correspondence: khaled.elhaies@gmail.com
}

Received: 5 April 2020; Accepted: 26 April 2020; Published: 29 April 2020

check for updates

\begin{abstract}
The impact of biochar and chitosan on barley plants under drought stress conditions was investigated during two field experiments. Our results confirmed that drought stress negatively affected morphological and physiological growth traits of barley plants such as plant height, number of leaves, chlorophyll concentrations, and relative water content. However, electrolyte leakage (EL\%), lipid peroxidation (MDA), soluble sugars, sucrose and starch contents significantly increased as a response to drought stress. Additionally, 1000 grain weight, grains yield $\mathrm{ha}^{-1}$ and biological yield significantly decreased in stressed barley plants, also anatomical traits such as upper epidermis, lower epidermis, lamina, and mesophyll tissue thickness as well as vascular bundle diameter of flag leaves significantly decreased compared with control. The use of biochar and chitosan led to significant increases in plant height, number of leaves, and chlorophyll concentrations as well as relative water content; nevertheless these treatments led to significant decreases in electrolyte leakage (EL\%) and lipid peroxidation (MDA) in the stressed plants. Moreover, anatomical and yield characters of stressed barley plants were improved with application of biochar and chitosan. The results proved the significance of biochar and chitosan in alleviating the damaging impacts of drought on barley plants.
\end{abstract}

Keywords: barley; drought stress; biochar; chitosan; photosynthetic pigments; anatomical structure

\section{Introduction}

Barley is one of the most significant cereal crops of the Poaceae family and it is an important crop not only in Egypt but also all over the world. There are many biotic and abiotic stress factors affecting the plant growth and production such as plant diseases pathogens mainly net blotch disease in barley plants [1-3], rust diseases in wheat plants [4,5] and abiotic stress factors like drought and salinity [6-8]. 
Drought stress is one of the most detrimental factors seriously affecting the growth and production of many plants mostly during the flowering phases [9]. Under drought stress conditions, significant diminution in the growth parameters were recoded such as number of leaves, leaf area stem length in various plants $[10,11]$. Also, the crop yield and productivity were significantly affected under drought stress [12] in barley plants. During drought stress, the solutes such as organic acids, free amino acids, and carbohydrates were accumulated [13] in flax plants. The plants have many mechanisms in response to abiotic factors such as drought, salinity, cold and heat stress. These mechanisms are associated with morphological, physiological, and biochemical changes [14]. Under various abiotic stresses, the damaging effects on plants are associated with oxidative damage in the plant cells [15-17] resulting in increases in lipid peroxidation, reactive oxygen species (ROS), and electrolyte leakage $[6,7,18,19]$. Under normal conditions, ROS naturally exist in plant organelles, mainly mitochondria, chloroplasts, and peroxisomes, but in the stress conditions such as drought, ROS levels increase resulting in lipid peroxidation and proteins degradation [20]. Also, growth and physiological characters such as stem length, number of leaves, leaf area, relative water content, and chlorophyll concentration as well as yield production were decreased under abiotic and biotic stresses such as salinity, drought, and pathogens in many plants [4,5,21-24]. Recently, overuse of chemical fertilizers led to injurious effects on soil properties, soil valuable microorganisms, water quality, and human health [25]. There are many strategies to decrease the harmful effects of chemical fertilizers and mitigate the damaging effects of various stresses, one of the safe and effective strategies is application of some natural compounds such as biochar and chitosan.

Biochar is one of the important soil amendments because it is a rich source of many important nutrient elements such as carbon, nitrogen, and sulfur. It was obtained by the decomposition of the forest, residual plants, as well as manure residues under high temperature (200-900 $\left.{ }^{\circ} \mathrm{C}\right)$ without or with low oxygen concentration [26]. Biochar plays many positive roles in agricultural production such as in composting improvement [27], in mitigation of salinity and drought stress [28], and in improving crop production [29]. Application of biochar enhanced the absorption of many nutrients in kiwi plants [30], and significantly increased magnesium, phosphorus, and nitrogen contents in corn plants [31]. Nutrients uptake and chlorophyll concentrations increased with biochar application at rate $20 \mathrm{t} \mathrm{ha}^{-1}$ in pumpkin plants under drought conditions [32]. Under natural and stressful conditions, biochar gave significant results of growth characters and yield production [33]. Application of biochar increased nutrient uptake and enhanced plant growth in drought-stressed maize plants [34].

Chitosan is a polysaccharide consists of two molecules of monosaccharaides ( $\mathrm{N}$-acetyl Dglucosamine (GlcNAc)) linked by $\beta-1,4$ glycosidic bonds [35]. It has a promising role in many fields because of biological activities and non-toxicity mainly in agricultural production. Chitosan has a positive effect on plants under pathogens and abiotic stress. Chitosan application can support the defense system, enhances the plant growth characters (plant height, leaf area, chlorophyll concentrations) under many abiotic stress factors, mainly drought stress by the stimulation of antioxidant system in many plants such as rice plants [36]. Foliar spray application of chitosan increase plant height, leaves number, and yield production [37], it can improve growth characters, chlorophyll concentration, and nutrient uptake [38]. Seed treatments with chitosan led to prominent increase in germination rate, growth characters, and yield of soybean plants [39]. Under drought stress conditions, application of chitosan $\left(400 \mu \mathrm{L} \mathrm{L}^{-1}\right)$ led to an increase in dry matter of thyme plants (Thymus daenensis) [40]. Regarding to the drought conditions, there are many plants that are adapted to arid lands, these plants are identified as xeromorphy and have xeromorphic anatomical characters such as decreased leaf area, increased thickness of epidermis cell wall and cuticle [41,42]. Plants showed many various responses such as anatomical changes under stress conditions [43]. Until now, a little information is available about the impact of biochar and chitosan on anatomical structure of droughted stressed plants. Thus, the objective of our research is to study the effect of biochar and chitosan on inducing tolerance in barley plants to drought stress, through evaluating the antioxidant enzymes activity, osmolytes accumulation, yield, and anatomical characters. 


\section{Materials and Methods}

\subsection{Plant Materials and Experiment Preparation}

During two successive winter seasons 2017/2018 and 2018/2019, field experiments were carried out in a private farm under field conditions, Al-mahalla Al-Kobra region, El-Gharbia Governorate, Egypt to study the effect biochar and chitosan on antioxidative capacity, osmolytes accumulation, yield, and anatomical characters of barley plants under drought stress conditions. The physiological, biochemical and anatomical studies were carried out at Excellence Center (EPCRS) and Plant Pathology and Biotechnology Lab. (certified according to ISO 9001, ISO 14001, OHSAS 18001 and ISO 17025), Department of Agricultural Botany, Kafrelsheikh University, Kafr Elsheikh, Egypt. The weather conditions of the experimental location are presented in Table 1 according to NASA POWER Data Access Viewer-Prediction of Worldwide Resource (https://power.larc.nasa.gov/data-access-viewer).

Table 1. The weather conditions of the experimental location during two growing seasons from sowing to harvesting date.

\begin{tabular}{cccccccc}
\hline Meteorological Data & Season & December & January & February & March & April & May \\
\hline Precipitation $\left(\mathrm{mm} \mathrm{day}^{-1}\right)$ & 2017 & 8.36 & 7.78 & 7.85 & 0.58 & 47.42 & 0.03 \\
& 2018 & 8.13 & 32.80 & 10.80 & 1.61 & 3.09 & 0.01 \\
Relative humidity at $2 \mathrm{~m}(\%)$ & 2017 & 67.35 & 68.84 & 67.23 & 63.81 & 59.35 & 53.37 \\
& 2018 & 67.82 & 68.49 & 67.61 & 55.02 & 54.00 & 54.25 \\
Maximum temperature at $2 \mathrm{~m}\left({ }^{\circ} \mathrm{C}\right)$ & 2017 & 21.88 & 17.16 & 18.86 & 21.86 & 25.25 & 29.92 \\
& 2018 & 19.65 & 18.69 & 20.99 & 25.41 & 27.58 & 31.35 \\
Minimum temperature at $2 \mathrm{~m}\left({ }^{\circ} \mathrm{C}\right)$ & 2017 & 14.21 & 9.70 & 10.37 & 12.50 & 14.21 & 18.37 \\
& 2018 & 13.66 & 11.64 & 12.15 & 13.66 & 15.76 & 19.90 \\
\hline
\end{tabular}

Barley grains (Hordeum vulgare L. var. Giza123) $\left(120 \mathrm{~kg}_{\text {grains }} \mathrm{ha}^{-1}\right.$ ) were sown on 3rd December in the first season and 2nd December in the second season. The experimental design was a randomized complete block design with three replicates, the experimental unit was $2 \times 2 \mathrm{~m}$, and the irrigation system was surface irrigation. The physical and chemical characteristics of the experimental soil were studied according to Association of Officinal Analytical Chemists (A.O.A.C 2005) [44] as follows: electrical conductivity $1.7 \mathrm{dS} \mathrm{m}^{-1}$, available $n 33.1 \mathrm{ppm}$, available $p 10.3 \mathrm{ppm}$, available K $286 \mathrm{ppm}$, sand $17.6 \%$, silt $35.8 \%$, clay $47.6 \%$, $\mathrm{pH}$ (water) 8.1 , and texture clay. The recommended doses of NPK were added as the recommendations of ministry of agriculture and land reclamation. The treatments were done as follow: plants received three irrigations (control), well-watered ( $2000 \mathrm{~m}^{3}$ water) as per the recommendations under field conditions, plants received one irrigation only after germination (D1) stressed plants $\left(650 \mathrm{~m}^{3}\right.$ water), plants received two irrigations after germination (D2) stressed plants (1300 $\mathrm{m}^{3}$ water), plants received one irrigation and treated with $20 \mathrm{t}$ biochar (D1 + biochar), plants received one irrigation and treated with $400 \mu \mathrm{L} \mathrm{L}^{-1} \mathrm{ha}^{-1}$ chitosan (D1 + chitosan), plants received two irrigations and treated with $20 \mathrm{t} \mathrm{ha}^{-1}$ biochar (D2 + biochar), plants received two irrigations and treated with $400 \mu \mathrm{L} \mathrm{L}^{-1} \mathrm{ha}^{-1}$ chitosan (D2 + chitosan). The harvest date was on 7 th and 12th May in both seasons respectively.

The samples were randomly taken at anthesis date to study the growth and physiological characters.

\subsection{Growth Characters}

The samples were randomly taken at anthesis date (ten plants from each plot) to study plant height, number of leaves, and leaf area/plant.

\subsection{Determination of Chlorophyll a and Chlorophyll b Concentrations as well as Relative Water Content (RWC\%)}

Fresh flag leaf ( $0.5 \mathrm{~g})$ was homogenized with acetone $(90 \% \mathrm{v} / \mathrm{v})$, filtered, and make up to a final volume of $50 \mathrm{~mL}$. The absorbance was measured spectrophotometrically at 663 and $648 \mathrm{~nm}$ to measure chlorophyll a and chlorophyll b concentrations [45]. 
Relative water content was recorded as follow:

$$
\mathrm{RWC}=(\mathrm{FW}-\mathrm{DW}) /(\mathrm{TW}-\mathrm{DW}) \times 100
$$

According to Sanchez et al. (2004) [46], FW is fresh weight, DW is dry weight, TW is turgid weight.

\subsection{Determination of Electrolyte Leakage (EL\%), Lipid Peroxidation and Proline Content}

Electrolyte leakage (\%) was measured in fresh leaves. Twenty discs $\left(1 \mathrm{~cm}^{2}\right)$ were placed into flasks containing $25 \mathrm{~mL}$ deionized water, the flasks were shaken at ambient temperature $(20 \mathrm{~h})$ to facilitate electrolyte leakage from tissues. Initial electrical conductivity measurements were recorded. Flasks were then immersed in a hot water bath $\left(80^{\circ} \mathrm{C}\right)$ for $1 \mathrm{~h}$ to induce cell rupture. The samples were again placed on the shaker for $20 \mathrm{~h}$ at $21^{\circ} \mathrm{C}$. Final conductivity was measured for each flask. Electrolyte leakage $(\%)$ was calculated as follow: Initial conductivity/final conductivity $\times 100$ [47].

Determination of malondialdehyde (MDA) concentration. The concentration of MDA was measured according to the following formula:

$$
\operatorname{MDA}\left(\mathrm{nmol} \mathrm{g}^{-1} \mathrm{fw}\right)=[6.45 \times(\mathrm{A} 532-\mathrm{A} 600)-(0.56 \times \mathrm{A} 450)] \times \mathrm{V}^{-1} \mathrm{~W}
$$

where $\mathrm{V}=$ volume $(\mathrm{mL}), \mathrm{W}=$ weight $(\mathrm{g})[48]$.

Proline was assayed based on the reaction with ninhydrin, and the absorbance was determined at $520 \mathrm{~nm}$ as $\mu \mathrm{g} \mathrm{g}^{-1} \mathrm{FW}[49]$.

\subsection{Determination of Soluble Sugar, Sucrose and Starch Contents}

Samples of fresh leaves $(0.1 \mathrm{~g})$ were ground, extracted with $80 \%(\mathrm{v} / \mathrm{v})$ ethanol at $80{ }^{\circ} \mathrm{C}$ for $30 \mathrm{~min}$, and centrifuged for $10 \mathrm{~min}$ at $10,000 \times \mathrm{g}$. The extraction was done three times with $80 \%$ ethanol, the three supernatants were combined using $80 \%$ ethanol to a total volume of $5 \mathrm{~mL}$. Using Double-Beam spectrophotometer (Shimadzu, Columbia, Maryland, USA) at A620 nm and A489 nm, the soluble sugars and sucrose contents were measured, respectively [50]. The ethanol-insoluble residue was used to extract the starch by evaporation, $2 \mathrm{~mL}$ of distilled water was added into the samples and incubated for $15 \mathrm{~min}$ at $100^{\circ} \mathrm{C}$. Starch was hydrolyzed by $9.2 \mathrm{M}$ and $4.6 \mathrm{M} \mathrm{HClO}_{4}$ to the samples, individually. The starch content was determined with anthrone reagent using spectrophotometer at A620 nm [51].

\subsection{Antioxidant Enzymes Activity}

Fresh leaves ( $0.5 \mathrm{~g}$ flag leaf) were homogenized at $0-4{ }^{\circ} \mathrm{C}$ in $3 \mathrm{~mL}$ of $50 \mathrm{mM}$ TRIS buffer (pH 7.8), centrifuged $\left(12,000 \mathrm{rpm}, 20 \mathrm{~min}, 4^{\circ} \mathrm{C}\right)$, and the total soluble enzyme activities were measured in the supernatant using spectrophotometer. Catalase activity (CAT) was determined according to Aebi (1983) [52], while, activity of glutathione reductase (GR) was determined according to the methodology of Fryer et al. (1998) [53]. Activity of peroxidase (POX) was directly determined of the crude enzyme extract according to Hammerschmidt et al. (1982) [54]. The absorbance was recorded every $30 \mathrm{~s}$ intervals for $3 \mathrm{~min}$ at $470 \mathrm{~nm}$.

\subsection{Yield Characters}

Ten plants from each plot were taken at harvesting date (7th and 12th May in both seasons) to determine the yield characters, grains yield ha ${ }^{-1}$, biological yield ha ${ }^{-1}$, and 1000 grain weight.

\subsection{Anatomical Characters}

Barley leaves (0.5 cm length from the flag leaves) were taken during the second season 2018/2019 (50 days from the sowing). In formalin acetic acid alcohol (FAA), the leaves were killed and fixed. Next, the samples were washed and dehydrated in normal butyl alcohol [55]. Slides were examined and photomicrographed by light microscope. 


\subsection{Statistical Analysis}

The data were subjected to analysis of variance (ANOVA) procedures according to Gomez and Gomez (1984) [56] using the MSTAT-C Statistical Software package, East Lansing, MI, USA. The means were compared using Duncan (1955) [57] when the differences were significant $(p \leq 0.05)$.

\section{Results}

\subsection{Plant Height, Number of Leaves, Leaf Area/Plant, Chlorophyll Concentrations, and Relative Water Content (RWC \%)}

Under drought stress condition the exposed plants to drought conditions (one or two irrigations) showed significant reduction in plant height, number of leaves, and leaf area/plant compared with control plants (Figure 1). The maximum reduction was observed in the plants irrigated one time (D1) followed by the plants irrigated two time (D2) in the two growing seasons. The obtained data in Figure 1 indicated that, application of biochar and chitosan significantly improved plant height, number of leaves, and leaf area/plant in the stressed barley plants which received one or two irrigations in both seasons. The best results were obtained with control followed by the plants received two irrigations and treated with biochar (D2 + biochar) in the two seasons. According to data presented in Figure 1, the concentrations of chlorophyll $\mathrm{a}$ and $\mathrm{b}$ as well as relative water content were significantly reduced in the stressed plants in the two seasons. The plants that received one irrigation showed the minimum concentrations of chlorophyll a and chlorophyll $b$ as well as relative water content compared with the plants that received two irrigations and control plants (well-watered). Nevertheless, when stressed plants were treated with biochar and chitosan, chlorophyll a and b concentrations as well as relative water content significantly increased under drought conditions in the two seasons. Among all treatments, the high concentrations of chlorophyll and relative water content were recorded in the stressed treated barley plants which received two irrigations and treated with biochar.

\subsection{Effect of Biochar and Chitosan on Electrolyte Leakage (EL\%), Lipid Peroxidation and Proline Content}

The obtained results in Figure 2 pointed out that electrolyte leakage (EL\%), lipid peroxidation, and proline content significantly increased in the stressed plants in the both seasons. The maximum increases in electrolyte leakage, lipid peroxidation, and proline were recorded in the plants that received one irrigation and untreated with biochar or chitosan compared to the plants that received two irrigations. Contrariwise, electrolyte leakage, lipid peroxidation, and proline content were considerably influenced by biochar or chitosan application under drought conditions. Moreover, application of biochar or chitosan led to improved growth characters which caused decreases in electrolyte leakage, lipid peroxidation, and proline content, the best results were observed in the plants that received two irrigations under biochar application without any significant difference when compared with control plants.

\subsection{Soluble Sugars, Sucrose, and Starch Contents}

It is evident from Figure 3 that soluble sugars, sucrose, and starch contents were considerably increased in barley plants growing under drought conditions (one or two irrigations). The obtained results also showed that all treatments of biochar and chitosan significantly decreased soluble sugars, sucrose, and starch contents in the stressed barley plants with regard to control plants as well as stressed untreated plants which had the highest values of these characters. The plants that received two irrigations and treated with biochar showed the best results in the two seasons. 

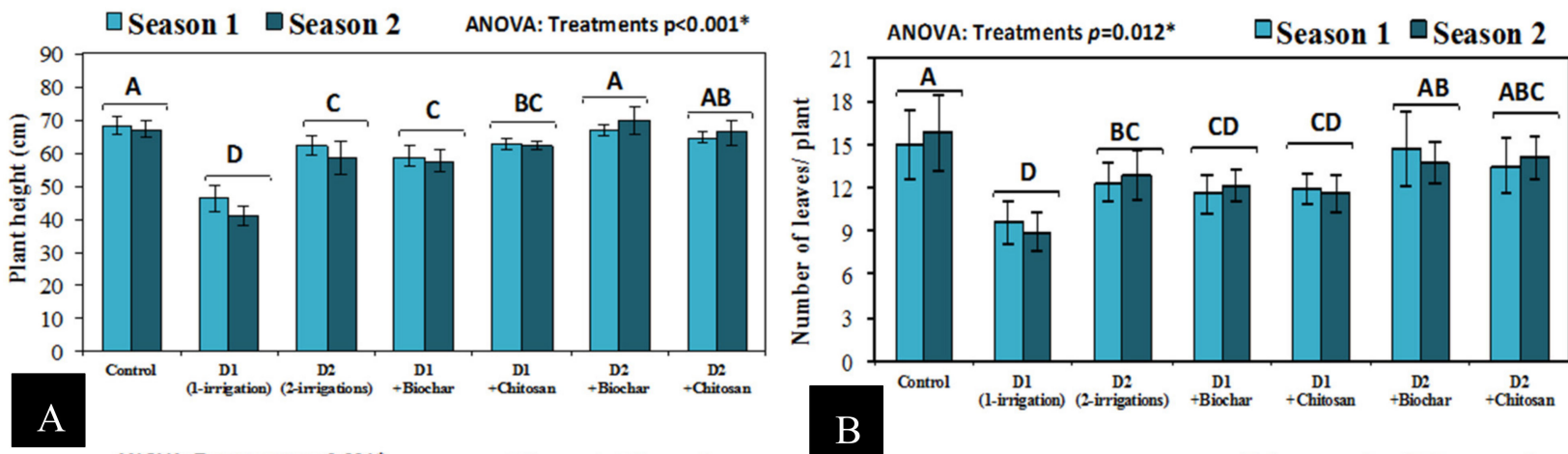

ANOVA: Treatments $p<0.001$

घSeason 1 घSeason 2

B
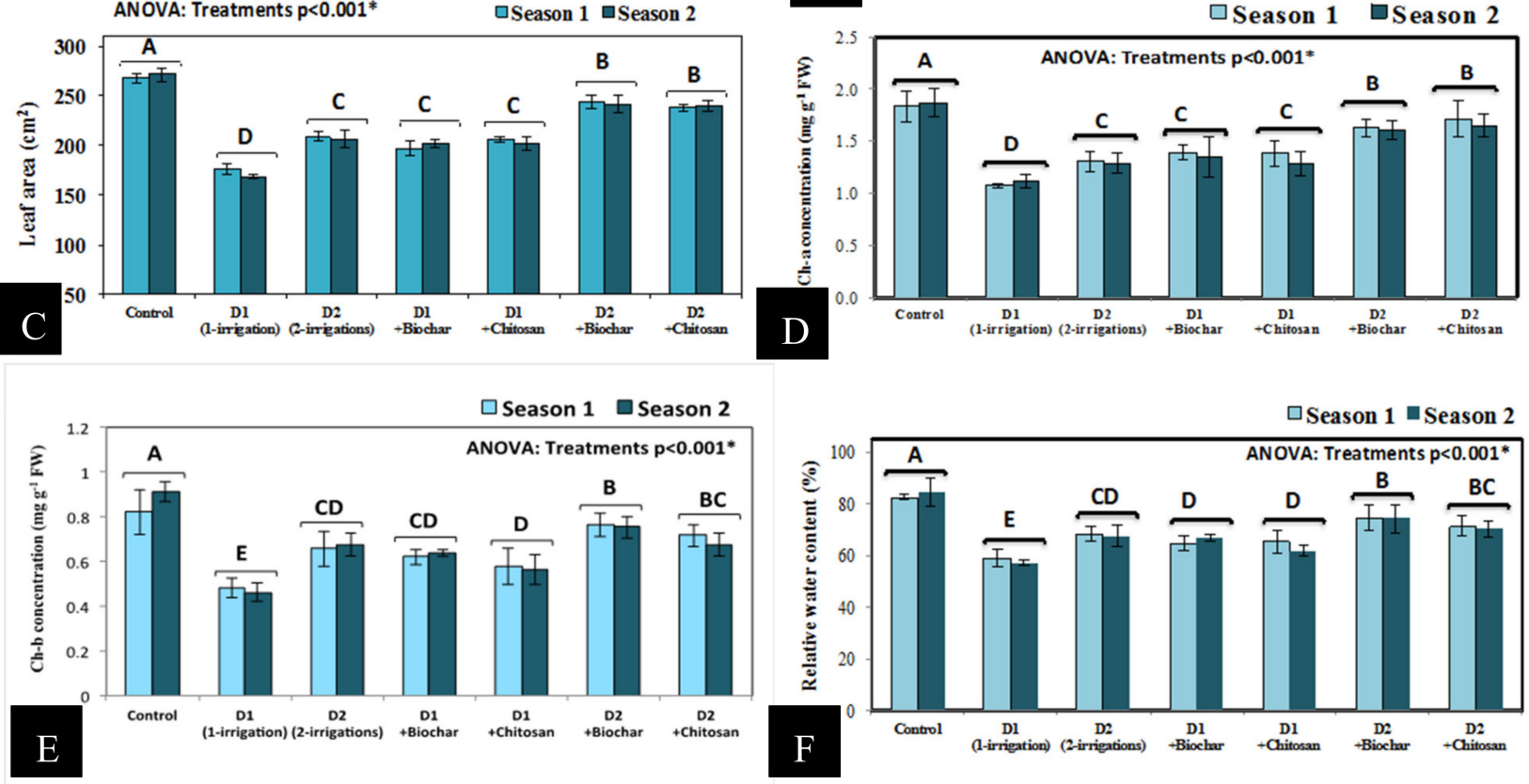

Figure 1. Effect of biochar and chitosan on plant height (A), number of leaves (B), leaf area (C), chlorophyll concentrations (D,E), and relative water content (F) of barley during two seasons (2017/2018-2018/2019). Bars followed by different letters are significantly different at $p<0.001$. (D1) One irrigation (D2) Two irrigations 

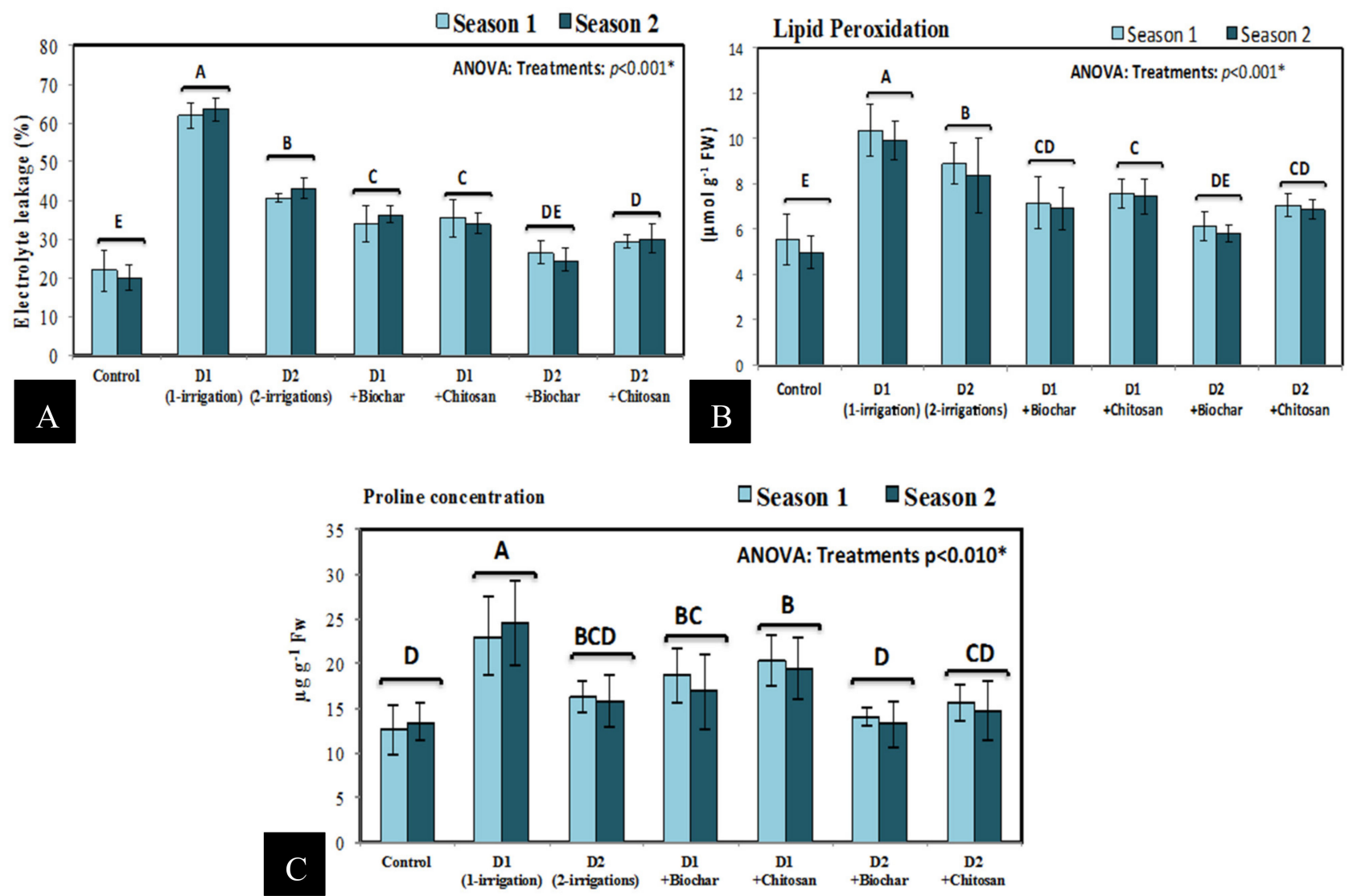

Figure 2. Effect of biochar and chitosan on electrolyte leakage (A), lipid peroxidation (B), and proline content (C) of barley during two seasons (2017/2018-2018/2019). Bars followed by different letters are significantly different at $p<0.001$. 


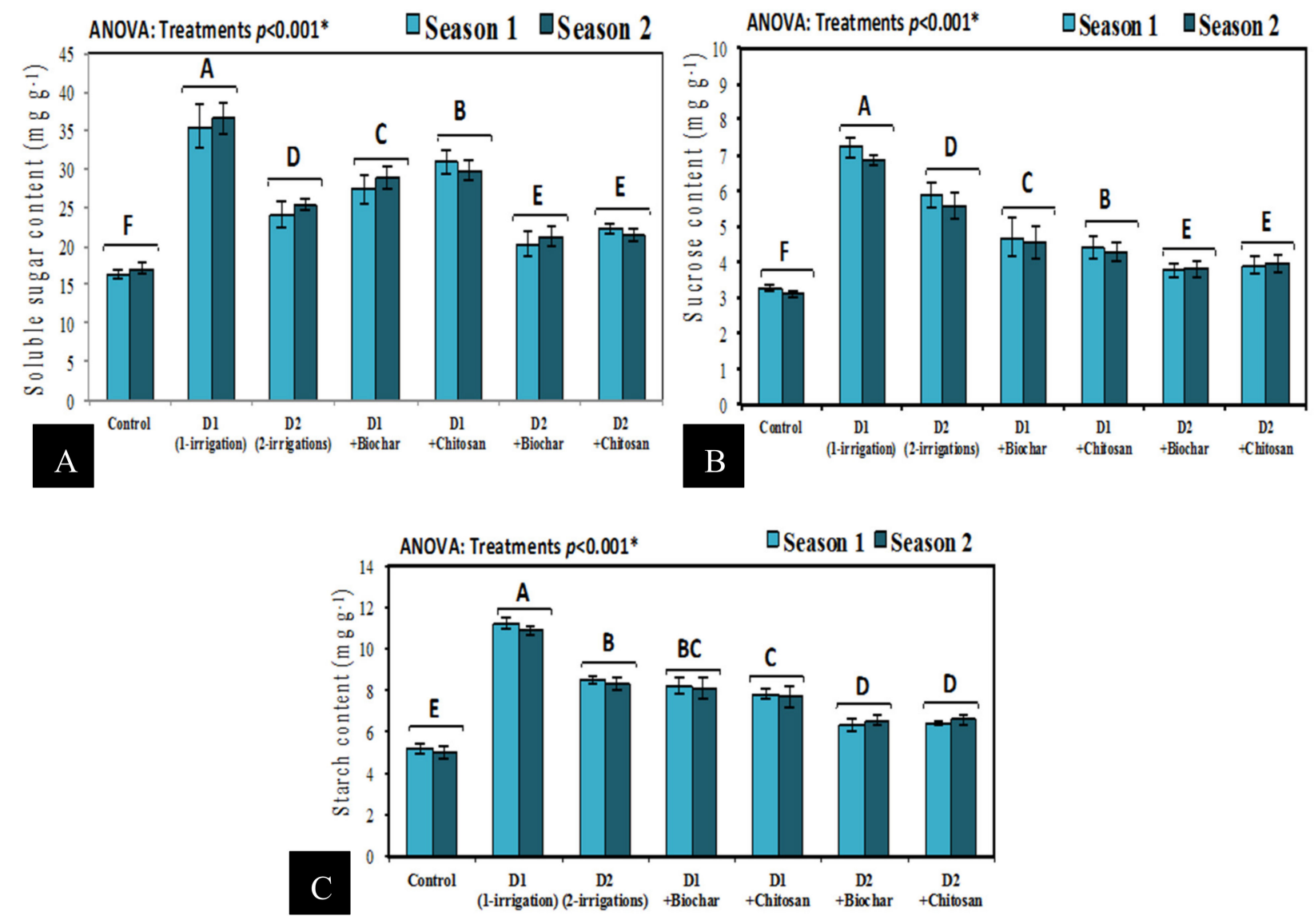

Figure 3. Effect of biochar and chitosan on soluble sugars (A), sucrose (B), and starch contents (C) of barley during two seasons (2017/2018-2018/2019). Bars followed by different letters are significantly different at $p<0.001$ 


\subsection{Antioxidant Enzymes Activity of Stressed Barley Plants Affected by Biochar and Chitosan Treatments}

Under drought stress conditions, the plants activate the defense system to scavenge reactive oxygen species which cause oxidative stress to plant organelles. In this experiment, exposed barley plants to drought stress showed significant increases in catalase, peroxidase, and glutathione reductase activities mainly in the plants that received one irrigation followed by the plants that received two irrigations in both seasons (Figure 4). In this study, we examined the impact of biochar and chitosan on catalase, peroxidase, and glutathione reductase activities of barley plants under drought conditions. Adding biochar to soil led to an improved activity of antioxidant enzymes around the optimum level like the control plants. Also, chitosan application led to an enhanced activity of POX, CAT, and GR in barley under drought conditions in both seasons. The best result was obtained with the plants treated with biochar and that received two irrigation.

\subsection{Effect of Biochar and Chitosan on Yield Characters (1000 Grain Weight, Grains Yield/ha, and Biological Yield/ha)}

The yield characters were significantly affected under drought stress with one or two irrigations; 1000 grain weight, grains yield ha ${ }^{-1}$, and biological yield ha ${ }^{-1}$ significantly decreased compared with the control well-watered plants in both seasons (Figure 5). The decrease in these characters was more effective in the plants that received one irrigation only compared to the plants that received two irrigation. Furthermore, 1000 grain weight, grains yield ha- ${ }^{-1}$, and biological yield ha ${ }^{-1}$ were significantly increased in the stressed barley plants which received one or two irrigations and treated with biochar and chitosan compared with stressed untreated plants in the two seasons, while there was no significant difference compared with the control well-watered plants. The highest values of 1000 grain weight, grains yield ha ${ }^{-1}$, and biological yield ha ${ }^{-1}$ were achieved with control well-watered plants and stressed plants (D2) treated with biochar compared with stressed untreated plants (D1 and D2) as well as the other treatments (Figure 5).

\subsection{Effect of Biochar and Chitosan on Anatomical Structure of Barley Leaves under Drought Conditions}

Our results demonstrated in Table 2 and Figure 6 revealed the means of five sections of each treatment and showed some modifications of anatomical structure of leaves caused by drought stress. Thickness of upper epidermis, lower epidermis, lamina, and mesophyll tissue, as well as vascular bundle diameter of flag leaves significantly decreased under drought conditions (Table 2 and Figure 6). The most reduction in all studied characters was recorded in the stressed plants that received one irrigation and untreated with biochar and chitosan (D) compared with control and stressed treated plants. Nevertheless, the treated plants with biochar and chitosan showed significant increases in thickness of upper and lower epidermis, lamina, and mesophyll tissue as well as vascular bundle diameter under the two levels of irrigation, the best results were recorded in the stressed plants that received two irrigations and treated with biochar and chitosan without any significant difference compared with the control plants (Table 2 and Figure 6). 

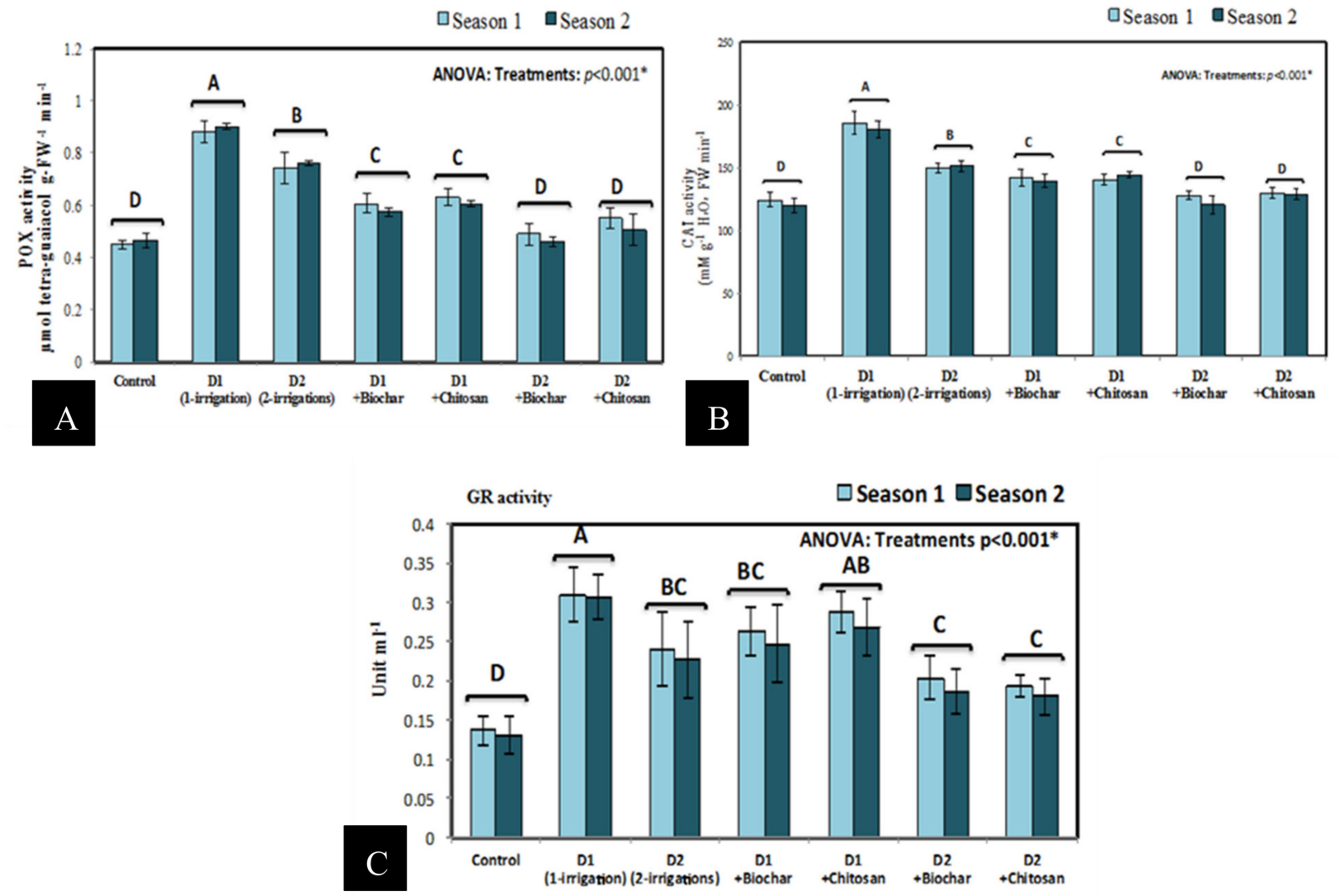

Figure 4. Effect of biochar and chitosan on antioxidant enzymes activity POX (A), CAT (B), and GR (C) of barley during two seasons (2017/2018-2018/2019). Bars followed by different letters are significantly different at $p<0.001$. 


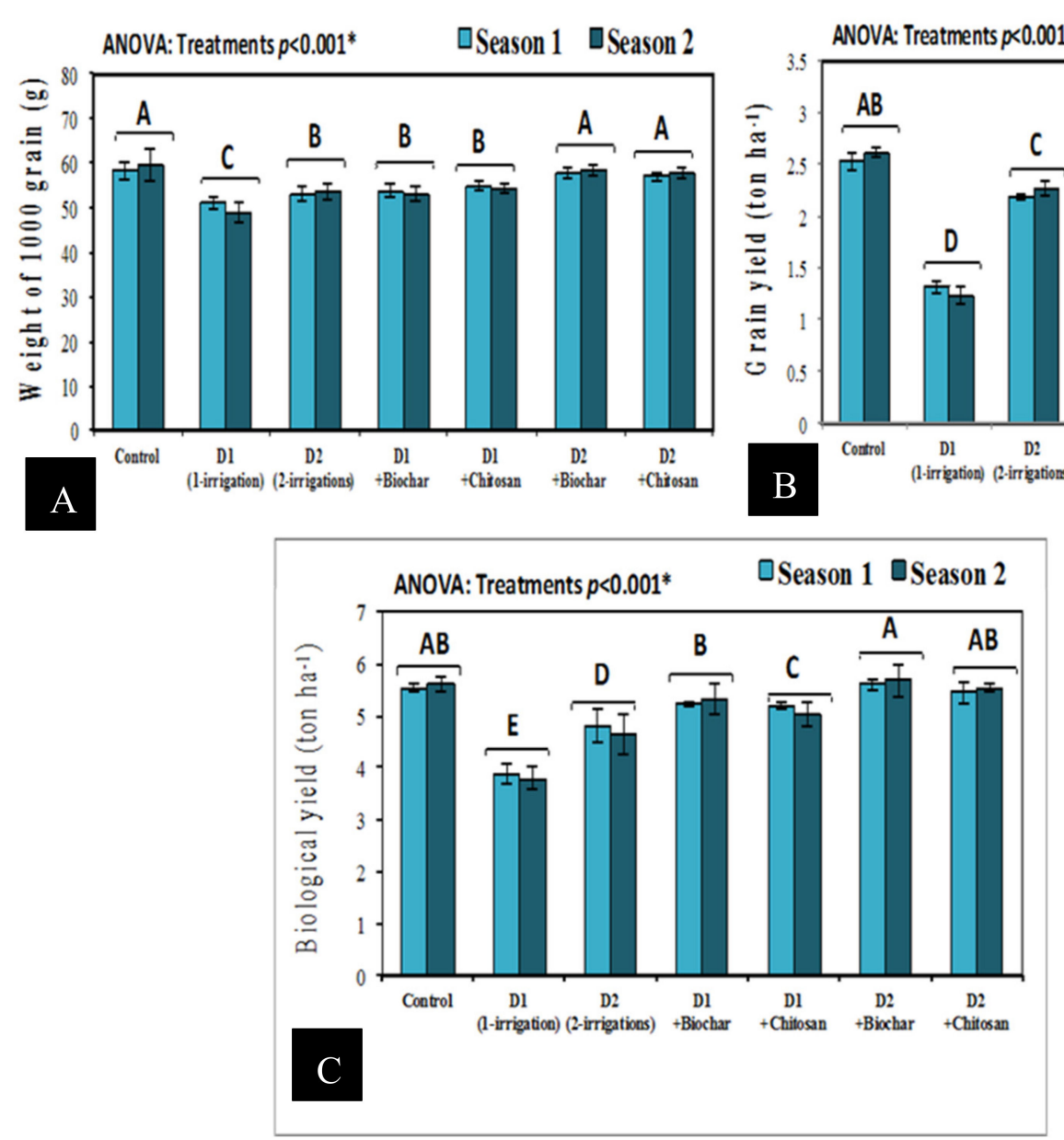

Figure 5. Effect of biochar and chitosan on yield characters; weight of 1000 grains (A), grain yield (B), and biological yield (C) of barley during two seasons (2017/2018-2018/2019). Bars followed by different letters are significantly different at $p<0.001$. 


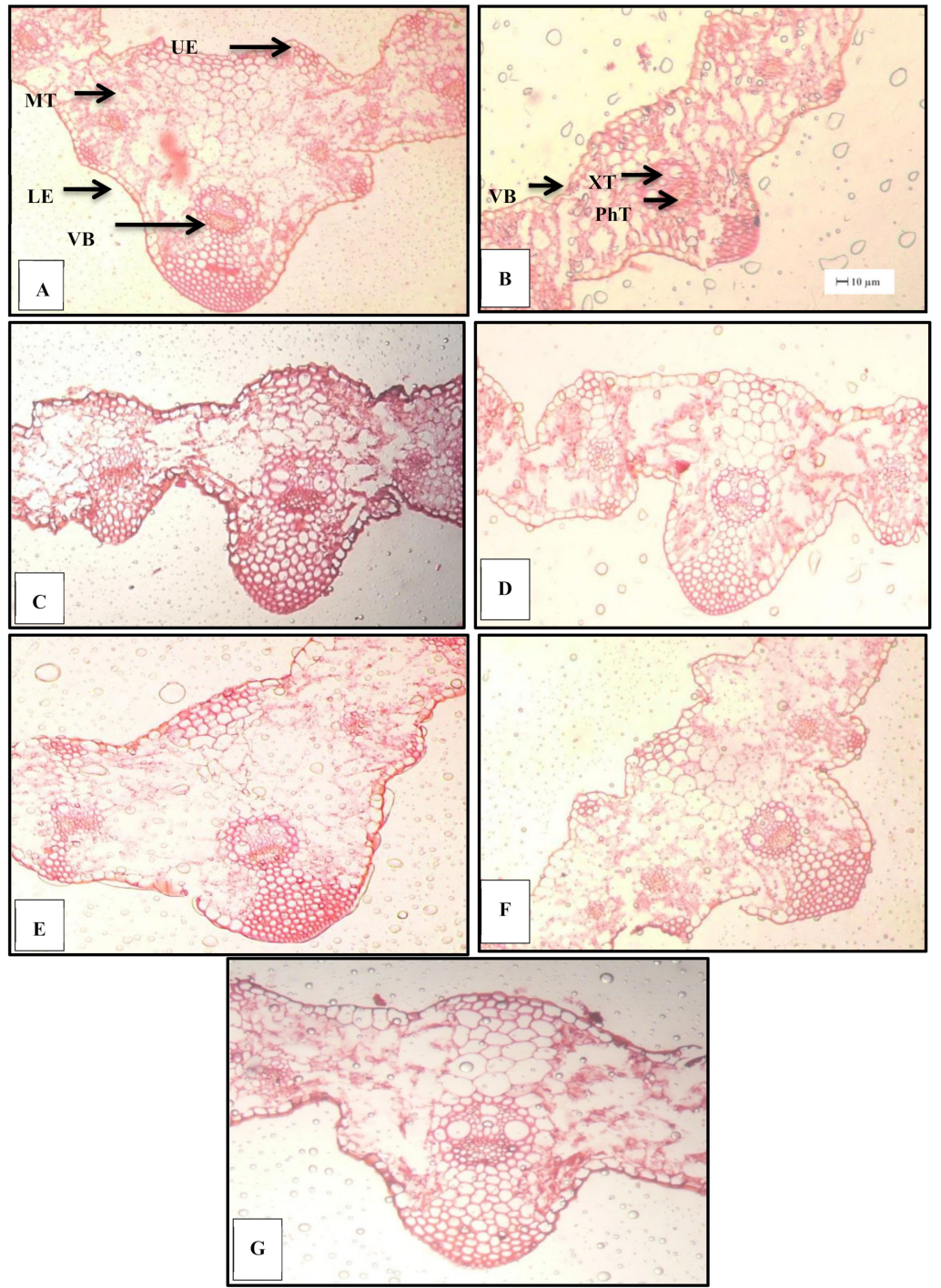

Figure 6. Transverse sections in flag leaves of barley plants in the second season. (A) Control (well-watered). (B) Plants received one irrigation (D1). (C) Plants received two irrigations (D2). (D) Plants received one irrigation and treated with biochar $(\mathrm{D} 1+\mathrm{BC})$. (E) Plants received one irrigation and treated with chitosan $(\mathrm{D} 1+\mathrm{CH})$. $(\mathrm{F})$ Plants received two irrigations and treated with biochar (D2 $+\mathrm{BC})$. (G) Plants received two irrigations and treated with chitosan (D2 + CH). $(\times 200)$. UE: upper epidermis, MT: mesophyll tissue, VB: vascular bundles, LE: lower epidermis, XT: xylem tissue, PhT: phloem tissue, $\mathrm{BC}$ : Biochar, $\mathrm{CH}$ : Chitosan

Table 2. Effect of biochar and chitosan on anatomical structure of barley leaves under drought conditions.

\begin{tabular}{cccccc}
\hline Treatments & $\begin{array}{c}\text { Thickness of Upper } \\
\text { Epidermis }(\mu \mathrm{m})\end{array}$ & $\begin{array}{c}\text { Thickness of Lower } \\
\text { Epidermis }(\mu \mathrm{m})\end{array}$ & $\begin{array}{c}\text { Thickness of } \\
\text { Lamina }(\mu \mathrm{m})\end{array}$ & $\begin{array}{c}\text { Thickness of } \\
\text { Mesophyll Tissue } \\
(\mu \mathrm{m})\end{array}$ & $\begin{array}{c}\text { Diameter of } \\
\text { Vascular Bundle } \\
(\mu \mathrm{m})\end{array}$ \\
\hline Control & $13.65 \mathrm{a}$ & $13.78 \mathrm{a}$ & $136.95 \mathrm{a}$ & $109.4 \mathrm{a}$ & $67.56 \mathrm{~b}$ \\
D1 (one irrigation) & $7.95 \mathrm{~d}$ & $8.14 \mathrm{~d}$ & $105.45 \mathrm{~d}$ & $87.49 \mathrm{e}$ & $61.42 \mathrm{e}$ \\
D2 (two irrigations) & $10.64 \mathrm{c}$ & $10.88 \mathrm{c}$ & $116.04 \mathrm{c}$ & $94.26 \mathrm{~d}$ & $66.07 \mathrm{c}$ \\
D1 + Biochar & $10.05 \mathrm{c}$ & $10.18 \mathrm{c}$ & $119.95 \mathrm{~b}$ & $98.44 \mathrm{c}$ & $64.76 \mathrm{~d}$ \\
D1 + Chitosan & $11.75 \mathrm{~b}$ & $11.24 \mathrm{~b}$ & $138.32 \mathrm{a}$ & $108.45 \mathrm{ab}$ & $68.84 \mathrm{~b}$ \\
D2 + Biochar & $12.75 \mathrm{a}$ & $12.88 \mathrm{a}$ & $137.86 \mathrm{a}$ & $111.02 \mathrm{a}$ & $68.47 \mathrm{~b}$ \\
D2 + Chitosan & $13.52 \mathrm{a}$ & $13.63 \mathrm{a}$ & $139.14 \mathrm{a}$ & $112.19 \mathrm{a}$ & $71.26 \mathrm{a}$ \\
\hline
\end{tabular}

The numbers followed by different letters are significantly different. 


\section{Discussion}

Drought stress has strong adverse effects on morphological, physio-biochemical, as well as yield and anatomical characters of the plants. According to our findings in Figure 1, the reduction in plant height, number of leaves, and leaf area/plant as well as relative water content in barley plants grown under drought stress could be due to the decrease in the soil solution absorption by the root system, and consequently reduce plant cell elongation and development as well as water content $[10,58]$. Likewise, chlorophyll $\mathrm{a}$ and $\mathrm{b}$ concentrations were significantly decreased under drought conditions (Figure 1); this harmful effect of drought stress may be due to the negative role of drought condition on photosynthetic enzymes activity mainly Calvin cycle enzymes and reactive oxygen species accumulation, which affect the chloroplast resulting in carbon assimilation reduction and decreased chlorophyll concentrations as well as inhibition of photosynthetic process. This negative effect was recorded under various stresses such as drought [22], salinity stress [7,19]. Application of biochar and chitosan significantly increased plant height, number of leaves, leaf area/plant, chlorophyll $a$ and chlorophyll $b$ concentrations as well as relative water content in stressed barley plants (Figure 1). The positive effect of biochar may be attributed to that, biochar increase soil content of elements such as carbon which, improve quality of soil, and led to increased relative water content and enhance plant height, number of leaves, leaf area/plant. This result of biochar application was similar to the obtained results of [59]. Furthermore, the increase of plant height, number of leaves, and leaf area/plant in the stressed plants treated with chitosan may be due to the significant role of chitosan as a protective factor against drought damage.

Electrolyte leakage (EL\%), lipid peroxidation, and proline content significantly increased with two treatments of drought (one irrigation (D1) and two irrigations (D2)) in both seasons compared with control plants (Figure 2), this increase is a response to water deficit stress and consistent with the obtained results of $[7,60]$. This result might be due to the harmful effect of drought on plasma membrane function and dehydration of cytoplasm, consequently, increase electrolyte leakage, lipid peroxidation, and proline content in barley plants under drought conditions. Use of biochar and chitosan against drought stress led to improved barley plant status associated with decreased electrolyte leakage, lipid peroxidation, and proline content. This positive effect of biochar and chitosan in diminishing electrolyte leakage, lipid peroxidation, and proline content because of biochar and chitosan may play a significant role in protecting plasma membrane stability, regulate water pressure, and improve relative water content as well as reduce oxidative stress resulting in decreasing lipid peroxidation. These progressive results are in agreement with the results of $[58,61]$. Drought stress causes decrease in growth parameters of barley plants associated with increase soluble sugars, sucrose, and starch contents (Figure 3), the increase was significant with the drought treatments, particularly, the plants that received one irrigation. The increase of these characters which are essential osmoprotectants may be an important approach in barley plants to adjust and cope with the drought conditions, for instance, the sucrose may converse into fructose and glucose which can regulate osmotic adjustment under drought conditions, these results are in harmony with those recorded by Wang et al. (2016) [9].

Likewise, the activity of antioxidant enzymes such as catalase, peroxidase, and glutathione reductase significantly increased under drought conditions to manage the accumulation of reactive oxygen species. The maximum levels of antioxidant enzymes activity were observed in the stressed plants that received one irrigation only followed by the plants that received two irrigations compared with control well-watered plants (Figure 4). The increasing enzymes activity in stressed barley plants is an important strategy to cope with the harmful effects of drought stress and scavenge reactive oxygen species which causes oxidative stress for plants. This effect of enzymes was observed under drought and various stresses [7,22,62]. Additionally, the treated barley plants with biochar and chitosan under the two treatments of drought conditions normalizes the activities of catalase, peroxidase, and glutathione reductase enzymes compared with stressed untreated plants and control plants. These valuable effects of biochar and chitosan in stressed plants were documented by [9]. 
Regarding to yield characters, drought conditions inhibits morphological growth characters such as plant height, number of leaves, and leaf area/plant and physiological parameters (relative water content, chlorophyll a and chlorophyll b concentrations). As we previously mentioned in Figures 1 and 2, this decrease led to detrimental effects and reduced yield characters mainly, 1000 grain weight, grains yield ha ${ }^{-1}$, and biological yield ha ${ }^{-1}$ (Figure 5). The reduction in yield characters was significant in the drought treatments (D1 and D2) compared with control plants and the stressed treated plants. This harmful impact of drought could be due to that drought negatively affects cell division and elongation, delay cellular growth, reduces photosynthetic rate, and finally decreases yield characters. This damaging effect of drought stress on yield production was revealed in many plants with some researchers [8,11-13]. On the other hand, the yield characters of barley plants significantly increased with application of biochar and chitosan; the increase was significant in the stressed treated plants compared with stressed untreated plants. These results showed that, biochar and chitosan play an important role in improving plant growth, increase nutrients uptake, enhance the concentrations of auxin and gibberellic acid [60], and consequently improve yield characters [32].

According to our results, drought stress induced anatomical changes in thickness of upper and lower epidermis, lamina and mesophyll tissue, as well as vascular bundle diameter. This negative and inhibition effect may result in water deficit from soil to plant organs, nutrients uptake reduction, leaf growth inhibition, decreased cell division and enlargement, reduced photosynthetic rate, and consequently decrease in anatomical characters of flag leaves. The same trend in many plants was recorded with drought stress $[22,63,64]$ and salinity stress $[16,19]$. Contrariwise, thickness of upper and lower epidermis, lamina and mesophyll tissue, as well as vascular bundle diameter significantly increased in the stressed treated plants with biochar and chitosan. This positive effect could be attributed to the availability of carbon and mineral nutrients as well as phytohormones such as gibberellin and indole acetic acid which improve the anatomical characters of flag leaves [61].

\section{Conclusions}

In conclusion, the use of biochar and chitosan can improve the tolerance of barley plants to drought stress conditions, this protection is closely connected with improvement of morphophysiological growth characters such as plant height, leaf area, chlorophyll concentrations, relative water content, and regulate antioxidant enzymes activity as well enhancement of anatomical characters of flag leaves such as thickness of upper and lower epidermis, lamina and mesophyll tissue, as well as vascular bundle diameter. The best results were achieved in the plants that received two irrigations and treated with biochar followed by the plants that received two irrigations and treated with chitosan. In our view the role of biochar and chitosan needs more attentions in the future in the agricultural production as harmless and friendly products to environment and to explain the mechanism of how biochar and chitosan relieve plants in stress conditions and their effects on the soil.

Author Contributions: Conceptualization, K.A. (Khaled Abdelaal), K.A. (Kotb Attia), and Y.H.; methodology, K.A. (Khaled Abdelaal), Y.H., K.A. (Kotb Attia), S.A., A.G., A.A.-D., E.R., L.E.-M., E.I.; validation, K.A. (Khaled Abdelaal), Y.H., K.A. (Kotb Attia), A.A.-D., E.R., L.E.-M., A.A.; formal analysis, K.A. (Khaled Abdelaal), Y.H., K.A. (Kotb Attia), E.R., L.E.-M., A.A. and E.I.; investigation, K.A. (Khaled Abdelaal), Y.H., K.A. (Kotb Attia), A.A., and E.R.; resources, K.A. (Khaled Abdelaal), Y.H., K.A. (Kotb Attia), S.A., and A.A.; data curation, K.A. (Khaled Abdelaal), Y.H., and K.A. (Kotb Attia); writing—original draft preparation, K.A. (Khaled Abdelaal), Y.H., K.A. (Kotb Attia), E.R., L.E.-M., and A.G.; writing-review and editing, K.A. (Khaled Abdelaal), Y.H., E.R., L.E.-M., A.A., and E.I.; supervision, K.A. (Kotb Attia) and Y.H.; funding acquisition, K.A. (Khaled Abdelaal), Y.H., K.A. (Kotb Attia), S.A., A.G., A.A.-D., E.R., L.E.-M., A.A., and E.I. All authors have read and agreed to the published version of the manuscript.

Funding: This research was funded by the Deanship of Scientific Research at King Saud University through research group No. (RG-1439-059).

Acknowledgments: The authors extend their appreciation to the Deanship of Scientific Research at King Saud University for funding this work through research group No. (RG-1439-059). Also the authors would like to thank all members of Plant Pathology and Biotechnology Lab. and EPCRS Excellence Centre (Accredited according to ISO/17025, ISO/9001, ISO/14001 and OHSAS/18001), Department of Agricultural Botany, Faculty of Agriculture, Kafrellsheikh University, Kafr-Elsheikh, Egypt. 
Conflicts of Interest: The authors declare conflicts of interest.

\section{References}

1. Hafez, Y.M.; Abdelaal, K.A.A.; Eid, M.E.; Mehiar, F.F. Morpho-physiological and biochemical responses of barley plants (Hordeum vulgare L.) against barley net blotch disease with application of non-traditional compounds and fungicides. Egypt. J. Biol. Pest Control 2016, 26, 261-268.

2. Hafez, Y.M.; Mourad, R.Y.; Mansour, M.; Abdelaal, K.A.A. Impact of non-traditional compounds and fungicides on physiological and biochemical characters of barely infected with Blumeria graminis $\mathrm{f}$. sp hordei under field conditions. Egypt. J. Biol. Pest Control 2014, 24, 445-453.

3. El-Nashaar, F.; Hafez, Y.M.; Abdelaal, K.A.A.; Abdelfatah, A.; Badr, M.; El-Kady, S.; Yousef, A. Assessment of host reaction and yield losses of commercial barley cultivars to Drechslera teres the causal agent of net blotch disease in Egypt. Fresenius Environ. Bull. 2020, 29, 2371-2377.

4. Omara, R.I.; El-Kot, G.A.; Fadel, F.M.; Abdelaal, K.A.A.; Saleh, E.M. Efficacy of Certain Bioagents on patho-physiological characters of wheat plants under wheat leaf rust stress. Physiol. Mol. Plant Pathol. 2019, 106, 102-108. [CrossRef]

5. Esmail, S.M.; Omara, R.I.; Abdelaal, K.A.A.; Hafez, M. Histological and biochemical aspects of compatible and incompatible wheat-Puccinia striiformis interactions. Physiol. Mol. Plant Pathol. 2019, 106, 120-128. [CrossRef]

6. EL-Sabagh, A.; Abdelaal, K.A.A.; Barutcular, C. Impact of antioxidants supplementation on growth, yield and quality traits of canola (Brassica napus L.) under irrigation intervals in North Nile Delta of Egypt. J. Exp. Biol. Agric. Sci. 2017, 5, 163-172.

7. Abdelaal, K.A.A.; EL-Maghraby, L.M.; Elansary, H.; Hafez, Y.M.; Ibrahim, E.I.; El-Banna, M.; El-Esawi, M.; Elkelish, A. Treatment of sweet pepper with stress tolerance-inducing compounds alleviates salinity stress oxidative damage by mediating the physio-biochemical activities and antioxidant systems. Agronomy 2020, 10, 26. [CrossRef]

8. Abdelaal, K.A.A.; Attia, K.A.; Alamery, S.F.; El-Afry, M.M.; Ghazy, A.I.; Tantawy, D.S.; Al-Doss, A.A.; El-Shawy, E.E.; Abu-Elsaoud, A.M.; Hafez, Y.M. Exogenous application of proline and salicylic acid can mitigate the injurious impacts of drought stress on barley plants associated with physiological and histological characters. Sustainability 2020, 12, 1736. [CrossRef]

9. Wang, R.; Gao, M.; Ji, S.; Wang, S.; Meng, Y.; Zhou, Z. Carbon allocation, osmotic adjustment, antioxidant capacity and growth in cotton under long-term soil drought during flowering and boll-forming period. Plant Physiol. Biochem. 2016, 107, 137-146. [CrossRef]

10. Abdelaal, K.A.A. Effect of Salicylic acid and Abscisic acid on morpho-physiological and anatomical characters of faba bean plants (Vicia faba L.) under drought stress. J. Plant Prod. Mansoura Univ. 2015, 6, 1771-1788. [CrossRef]

11. Abdelaal, K.A.A.; Hafez, Y.M.; EL Sabagh, A.; Saneoka, H. Ameliorative effects of Abscisic acid and yeast on morpho-physiological and yield characteristics of maize plant (Zea mays L.) under drought conditions. Fresenius Environ. Bull. 2017, 26, 7372-7383.

12. Samarah, N.H. Effects of drought stress on growth and yield of barley. Agron. Sustain. Dev. 2005, 25, 145-149. [CrossRef]

13. Rashwan, E.A.A.; Abdelaal, K.A.A. Effect of Nano Zink-oxide foliar application on some flax cultivars under different irrigation treatments. Egypt. J. Plant Breed. 2019, 23, 119-145.

14. McCue, K.F.; Hanson, A.D. Drought and salt tolerance: Towards understanding and application. Tibtechnology 1990, 8, 358. [CrossRef]

15. Mittler, R. Oxidative stress, tolerance antioxidants and stress. Trends Plant Sci. 2002, 7, 405-410. [CrossRef]

16. Helaly, M.N.; Mohammed, Z.; El-Shaeery, N.I.; Abdelaal, K.A.A.; Nofal, I.E. Cucumber grafting onto pumpkin can represent an interesting tool to minimize salinity stress. Physiological and anatomical studies. Middle E. J. Agric. Res. 2017, 6, 953-975.

17. Abdelaal, K.A.A.; Omara, I.R.; Hafez, Y.M.; Esmail, S.M.; EL Sabagh, A. Anatomical, biochemical and physiological changes in some Egyptian wheat cultivars inoculated with Puccinia graminis f. sp. tritici. Fresenius Environ. Bull. 2018, 27, 296-305. 
18. Asada, K. Production and scavenging of reactive oxygen species in chloroplasts and their functions. Plant Physiol. 2006, 141, 391-396. [CrossRef]

19. El-Banna, M.F.; Abdelaal, K.A.A. Response of strawberry plants grown in the hydroponic system to pretreatment with $\mathrm{H} 2 \mathrm{O} 2$ before exposure to salinity stress. J. Plant Prod. Mansoura Univ. 2018, 9, 989-1001. [CrossRef]

20. Huang, S.; Van Aken, O.; Schwarzlnder, M.; Belt, K.; Millar, A.H. The roles of mitochondrial reactive oxygen species in cellular signaling and stress responses in plants. Plant Physiol. 2016, 171, 1551-1559. [CrossRef]

21. Hasan, M.K.; El Sabagh, A.; Sikdar, M.S.; Alam, M.J.; Ratnasekera, D.; Barutcular, C.; Abdelaal, K.A.; Islam, M.S. Comparative adaptable agronomic traits of blackgram and mungbean for saline lands. Plant Arch. 2017, 17, 589-593.

22. Abdelaal, K.A.A.; Hafez, Y.M.; El-Afry, M.M.; Tantawy, D.S.; Alshaal, T. Effect of some osmoregulators on photosynthesis, lipid peroxidation, antioxidative capacity, and productivity of barley (Hordeum vulgare L.) under water deficit stress. Environ. Sci. Pollut. Res. 2018, 25, 30199-30211. [CrossRef] [PubMed]

23. Omara, R.I.; Abdelaal, K.A.A. Biochemical, histopathological and genetic analysis associated with leaf rust infection in wheat plants (Triticum aestivum L.). Physiol. Mol. Plant Pathol. 2018, 104, 48-57. [CrossRef]

24. Hafez, Y.M.; Mourad, R.Y.; Nasr, E.B.; Kotb, A.; Abdelaal, K.A.; Ghazy, A.I.; Al-Ateeq, T.K.; Ibrahim, E.I.; Mohammed, A.A. Biochemical and molecular characterization of non-host resistance keys in food crops. Saudi J. Biol. Sci. 2020, 27, 1091-1099. [CrossRef]

25. Boussemart, J.P.; Leleu, H.; Ojo, O. The spread of pesticide practices among cost-efficient farmers. Environ. Model. Assess. 2013, 18, 523-532. [CrossRef]

26. Sanchez-Reinoso, A.D.; Avila-Pedraza, E.A.; Restrepo-Diaz, H. Use of biochar in agriculture. Acta Biol. Colomb. 2020, 25. [CrossRef]

27. Sanchez-Monedero, M.A.; Cayuela, M.L.; Roig, A.; Jindo, K.; Mondini, C.; Bolan, N. Role of biochar as an additive in organic waste composting. Bioresour. Technol. 2018, 247, 1155-1164. [CrossRef]

28. Ali, S.; Rizwan, M.; Qayyum, M.F.; Ok, Y.S.; Ibrahim, M.; Riaz, M.; Arif, M.S.; Hafeez, F.; Al-Wabel, M.I.; Shahzad, A.N. Biochar soil amendment on alleviation of drought and salt stress in plants: A critical review. Environ. Sci. Pollut. Res. 2017, 24, 12700-12712. [CrossRef]

29. Agegnehu, G.; Srivastava, A.K.; Bird, M.I. The role of biochar and biochar compost in improving soil quality and crop performance: A review. Appl. Soil Ecol. 2017, 119, 156-170. [CrossRef]

30. Sorrenti, G.; Masiello, C.A.; Toselli, M. Biochar interferes with kiwifruit Fe-nutrition in calcareous soil. Geoderma 2016, 272, 10-19. [CrossRef]

31. Chng, H.Y.; Ahmed, O.H.; Majid, N.M.A. Improving phosphorus availability, nutrient uptake and dry matter production of Zea mays L. on a tropical acid soil using poultry manure biochar and pineapple leaves compost. Exp. Agric. 2015, 52, 447-465. [CrossRef]

32. Langeroodi, A.R.S.; Campiglia, E.; Mancinelli, R.; Radicetti, E. Can biochar improve pumpkin productivity and its physiological characteristics under reduced irrigation regimes? Sci. Hortic. 2019, 247, 195-204. [CrossRef]

33. Xu, G.; Zhang, Y.; Sun, J.; Shao, H. Negative interactive effects between biochar and phosphorus fertilization on phosphorus availability and plant yield in saline sodic soil. Sci. Total Environ. 2016, 568, 910-915. [CrossRef] [PubMed]

34. Haider, G.; Koyro, H.W.; Azam, F.; Steffens, D.; Muller, C.; Kammann, C. Biochar but not humic acid product amendment affected maize yields via improving plant-soil moisture relations. Plant Soil 2015, 395, 141-157. [CrossRef]

35. Katiyar, D.; Hemantaranjan, A.; Singh, B.; Bhanu, A.N. A future perspective in crop protection: Chitosan and its oligosaccharides. Adv. Plants Agric. Res. 2014, 1, 1-8.

36. Pongprayoon, W.; Roytrakul, S.; Pichayagkura, R.; Chadchawan, S. The role of hydrogen peroxide in chitosan-induced resistance to osmotic stress in rice (Oryza sativa L.). Plant Growth Regul. 2013, 70, 159-173. [CrossRef]

37. Monirul, I.M.; Humayun, K.M.; Mamun, A.N.K.; Monirul, I.; Pronabananda, D. Studies on yield and yield attributes in tomato and chilli using foliar application of oligo-chitosan. GSC Biol. Pharm. Sci. 2018, 3, 020-028.

38. Ahmed, K.B.M.; Khan, M.M.A.; Siddiqui, H.; Jahan, A. Chitosan and its oligosaccharides, a promising option for sustainable crop production-A review. Carbohydr. Polym. 2020, 227, 115331. [CrossRef] 
39. Zeng, D.; Luo, X.; Tu, R. Application of bioactive coatings based on chitosan for soybean seed protection. Int. J. Carbohydr. Chem. 2012. [CrossRef]

40. Bistgani, Z.E.; Siadat, S.A.; Bakhshandeh, A.; Pirbalouti, A.G.; Hashemi, M. Morpho-physiological and phytochemical traits of (Thymus daenensis Celak.) in response to deficit irrigation and chitosan application. Acta Physiol. Plant. 2017, 39, 231. [CrossRef]

41. Fahn, A.; Cutler, D.F. Xerophytes; Gebrüder Borntraeger: Berlin, Germany, 1992; pp. 1-107.

42. Dickison, W.C. Integrative Plant Anatomy; Academic Press: San Diego, CA, USA, 2000.

43. Nicotra, A.B.; Davidson, A. Adaptive phenotypic plasticity and plant water use. Funct. Plant Biol. 2010, 37, 117-127. [CrossRef]

44. Association of Official Analytical Chemists (A.O.A.C.). Official Methods of Analysis, 26th ed.; A.O.A.C. International: Washington, DC, USA, 2005.

45. Lichtenthaler, H.K. Chlorophylls and carotenoids: Pigments of photosynthetic bio-membranes. Methods Enzymol. 1987, 148, 350-382.

46. Sanchez, F.J.; de Andrés, E.F.; Tenorio, J.L.; Ayerbe, L. Growth of epicotyls, turgor maintenance and osmotic adjustment in pea plants (Pisum sativum L.) subjected to water stress. Field Crops Res. 2004, 86, 81-90. [CrossRef]

47. Szalai, G.; Janda, T.; Padi, E.; Szigeti, Z. Role of light in post-chilling symptoms in maize. J. Plant Physiol. 1996, 148, 378-383. [CrossRef]

48. Davenport, S.B.; Gallego, S.M.; Benavides, M.P.; Tomaro, M.L. Behavior of anti-oxidant defense system in the adaptive response to salt stress in (Helianthus annuus L.) cell. Plant Growth Reg. 2003, 40, 81-88. [CrossRef]

49. Bates, L.S.; Waldren, R.P.; Teare, I.D. Rapid determination of free proline for water-stress studies. Plant Soil 1973, 39, 205-207. [CrossRef]

50. Xu, W.; Cui, K.; Xu, A.; Nie, L.; Huang, J.; Peng, S. Drought stress condition increases root to shoot ratio via alteration of carbohydrate partitioning and enzymatic activity in rice seedlings. Acta Physiol. Plant. 2015, 37. [CrossRef]

51. Kuai, J.; Liu, Z.; Wang, Y.; Meng, Y.; Chen, B.; Zhao, W.; Zhou, Z.; Oosterhuis, D.M. Waterlogging during flowering and boll forming stages affects sucrose metabolism in the leaves subtending the cotton boll and its relationship with boll weight. Plant Sci. 2014, 223, 79-98. [CrossRef]

52. Aebi, H.E. Catalase. In Methods of Enzymatic Analysis, 3rd ed.; Verlag Chemie: Weinheim, Germany, 1983; pp. 273-286.

53. Fryer, M.J.; Andrews, J.R.; Oxborough, K.; Blowers, D.A.; Baker, N.R. Relationship between $\mathrm{CO}_{2}$ assimilation, photosynthetic electron transport, and active $\mathrm{O}_{2}$ metabolism in leaves of maize in the field during periods of low temperature. Plant Physiol. 1998, 116, 571-580. [CrossRef]

54. Hammerschmidt, R.; Nuckles, E.M.; Kuć, J. Association of enhanced peroxidase activity with induced systemic resistance of cucumber to Colletotrichum lagenarium. Physiol. Plant Pathol. 1982, 20, 73-82. [CrossRef]

55. Nassar, M.A.; El-Sahhar, K.F. Botanical Preparations and Microscopy (Microtechnique); Academic Bookshop: Giza, Egypt, 1998; p. 219.

56. Gomez, K.A.; Gomez, A.A. Statistical Procedures for Agricultural Research, 2nd ed.; Wiley Inter Science: New York, NY, USA, 1984; pp. 1-690.

57. Duncan, B.D. Multiple ranges and multiple F-test. Biometrics 1955, 11, 1-42. [CrossRef]

58. Boyer, J.S. Cell enlargement and growth - Induced water potentials. Physiol. Plant. 1988, 73, 311-316. [CrossRef]

59. Wei, W.; Yang, H.; Fan, M.; Chen, H.; Guo, D.; Cao, J.; Kuzyakov, Y. Biochar effects on crop yields and nitrogen loss depending on fertilization. Sci. Total Environ. 2020, 702, 134423. [CrossRef]

60. Hussain, M.; Malik, M.A.; Farooq, M.; Ashraf, M.Y.; Cheema, M.A. Improving drought tolerance by exogenous application of glycinebetaine and salicylic acid in sunflower. J. Agron. Crop Sci. 2008, 194, 193-199. [CrossRef]

61. Ahmed, A.H.H.; Nesiem, M.R.A.E.; Allam, H.A.; El-Wakil, A.F. Effect of preharvest chitosan foliar application on growth, yield and chemical composition of Washington navel orange trees grown in two different regions. Afr. J. Biochem. Res. 2016, 10, 59-69. [CrossRef]

62. Abdelaal, K.A.A.; Hafez, Y.M.; Badr, M.M.; Youseef, W.A.; Esmaeil, S.M. Biochemical, histological and molecular changes in susceptible and resistant wheat cultivars inoculated with stripe rust fungus Puccinia striiformis f. sp. tritici. Egypt. J. Biol. Pest Control 2014, 24, 421-429. 
63. Tardieu, F.; Reymond, M.; Hamard, P.; Granier, C.; Muller, B. Spatial distributions of expansion rate, cell division rate and cell size in maize leaves: A synthesis of the effects of soil water status, evaporative demand and temperature. J. Exp. Bot. 2000, 51, 1505-1514. [CrossRef] [PubMed]

64. Zhang, Y.; Equiza, M.A.; Zheng, Q.; Tyree, M.T. Factors controlling plasticity of leaf morphology in Robinia pseudoacacia L. II: The impact of water stress on leaf morphology of seedlings grown in a controlled environment chamber. Ann. For. Sci. 2012, 69, 39-47. [CrossRef] 